M.M. Jordán, M.B. Almendro-Candel, M. Romero, J.Ma. Rincón. Application of sewage sludge in the manufacturing of ceramic tile bodies

Applied Clay Science, 30 (2005) [3-4], 219-224; DOI: 10.1016/j.clay.2005.05.001

\title{
Application of sewage sludge in the manufacturing of ceramic tile bodies
}

\author{
M.M. Jordán ${ }^{\mathrm{a} *}$, M.B. Almendro-Candel ${ }^{\mathrm{a}}$, M. Romero ${ }^{\mathrm{b}}$, J.Ma. Rincón ${ }^{\mathrm{b}}$ \\ ${ }^{\mathrm{a} D e p a r t m e n t ~ o f ~ A g r o c h e m i s t r y ~ a n d ~ E n v i r o n m e n t, ~ U n i v e r s i t y ~ M i g u e l ~ H e r n a ́ n d e z, ~ E l c h e . ~}$ \\ Avda. de la Universidad s/n. 03202 ELCHE (Alicante), Spain \\ ${ }^{\mathrm{b}}$ Group of Glassy and Ceramic Materials, Instituto Eduardo Torroja de Ciencias de la \\ Construcción, CSIC, C/ Serrano Galvache 4, 28033 Madrid, Spain
}

\begin{abstract}
The substitution of clayey raw materials urban sewage sludge in the production of traditional ceramics could give place to a cost saving due to the utilisation of wastes as secondary raw material. At the same time, it can help to solve the environmental problems associated to such wastes. This research shows the results of the substitution of clay for sewage sludge in different proportions in a ceramic body. The sludge characterisation has been carried out by an analytical protocol. After that, the most suitable products were selected regarding to the chemical composition and the technological characterisation of the resulting ceramic material.
\end{abstract}

Keywords: Sewage sludge; Ceramic clays; Ceramic tiles; Recycling; Technological characterisation

\section{Introduction}

Due to determining environmental factors, the use of water treatment and purification process have been generalised worldwide, especially in those countries with an increasing scarcity of water resources. There are several water purification processes, but from every 
M.M. Jordán, M.B. Almendro-Candel, M. Romero, J.Ma. Rincón. Application of sewage sludge in the manufacturing of ceramic tile bodies

Applied Clay Science, 30 (2005) [3-4], 219-224; DOI: 10.1016/j.clay.2005.05.001

case and type of treatment, a waste denominated as "sewage sludge" is generated. If an integral treatment of the whole generated sewage were to be developed in Spain, and considering a population of 40 million habitants, a total production of about 3 million tons of sludge per year would be reached. After being composted and estimating between $60 \%$ and $70 \%$ of sludge are susceptible of agricultural use, we would reach about 500,000 tons of agriculturally composted sludge suitable per year (Bigeriego, 1993). At present, the disposal of these wastes takes place by three ways such as land or sea dumping, recycling or utilization with agricultural purposes, and finally incineration. Therefore, it is necessary to investigate for new applications for this type of waste.

Usually, the sewage sludge is a heterogeneous solid material which composition is quite variable depending not only on the origin of the effluent to be treated, but also on the technology used during its treatment. These processes will determine the different quantities of the sludge inorganic compounds (Sommers, 1977), and thus the extent to which those compounds are associated to the sludge organic fraction (Clapp et al., 1986). There are many reviews that develop statistical researches on the sludge composition. It is about a sludge rich in organic matter and in some elements such as $\mathrm{N}$ and $\mathrm{P}$. On the other hand, the sewage sludge despites a high electric conductivity due to its high salt concentration (Davis, 1989; Dondi et al., 1997; Navarro Pedreño et al., 1997). The origin of the effluent will determine the presence of toxic elements and agents. Sludge coming from wide urban areas with a substantial industrial influence, usually show higher concentrations of metals typical of factories such as $\mathrm{Cr}$ and $\mathrm{Ni}$. The treatment that the sewage receives during the purifying process may increase the existence of certain compounds in the sludge, especially ferric or aluminum salts added in order to favor the flocculation processes.

On the other hand, during the firing process of ceramic pastes takes place a series of reactions and transformations in the phyllosilicates and accompanying minerals like quartz, feldspar, calcite, dolomite and hematite, which will be decisive to establish the final properties of the ceramics products (Real, 1977; Jordán et al., 1999). The crystalline structures exceed its limits of stability and they partially decompose simultaneously that other phases are formed. But the destruction of the pre-existing structures is not an 
M.M. Jordán, M.B. Almendro-Candel, M. Romero, J.Ma. Rincón. Application of sewage sludge in the manufacturing of ceramic tile bodies

Applied Clay Science, 30 (2005) [3-4], 219-224; DOI: 10.1016/j.clay.2005.05.001

instantaneous effect (Jordán et al., 1999). There is a huge amount of literature on the disappearance and the neomineralization of clay bodies by firing. Clays for porous ceramic bodies were the subject of a study by Peters and Jenny (1973) and Pollifrone and Ravaglioly (1973). González-García et al. (1990) studied the formation of gehlenite and anorthite in calcareous clays, which were originally composed of illite, kaolinite, quartz and calcite. Jordán et al. (1993, 1994, 1995) and Almendro et al. (2001) studied the Cretaceous clays from Castellon and their behaviour when they were heat treated by fast firing. This study specifically discusses the behaviour of two calcareous clays from the areas around Agost (Alicante) and La Rioja (Spain) mixed with different quantities of sewage sludge. The geological and mineralogical characterisation of some ceramic pathologies in this ceramic clays were also carried out by Almendro et al. (2002), Jordán et al. (2002) and Miralles et al. (2002).

The aim of this work is to study the effect of the substitution of clay for sewage sludge in different proportions on the technological properties of a ceramic material.

\section{Materials and Methods}

\section{Characterisation of raw materials}

Two standard ceramic clays (RM1 and RM2) and three samples of sewage sludge (A, B and C) coming from three different sewage plants were selected. Tables 1 and 2 show the chemical composition (wt.\%) of the samples by X-ray fluorescence. Soluble $\mathrm{SO}_{4}{ }^{2-}$ and $\mathrm{Cl}^{-}$ (expressed in ppm) have been analysed by gravimetry and titration respectively. The total organic matter by calcination at $500^{\circ} \mathrm{C}$ while the loss of mass by calcination at $1000^{\circ} \mathrm{C}$ (Fernández, 2000). Finally, the $\mathrm{CaCO}_{3}$ content has been determined by calcimetry.

The content of heavy metals (Manrique Fournier et al., 1990) and trace elements were analysed by X-ray fluorescence in all the samples. The results of this analysis are summarised in Tables 3, 4, 5 and 6. 
M.M. Jordán, M.B. Almendro-Candel, M. Romero, J.Ma. Rincón. Application of sewage sludge in the manufacturing of ceramic tile bodies

Applied Clay Science, 30 (2005) [3-4], 219-224; DOI: 10.1016/j.clay.2005.05.001

Table 1 Chemical analysis of clays used as raw materials

\begin{tabular}{|c|c|c|c|}
\hline Parameter & Units & RM1 & RM2 \\
\hline O.M. $500{ }^{\circ} \mathrm{C}$ & $\%$ & 1.96 & 2.56 \\
\hline Deads $\left(1000^{\circ} \mathrm{C}\right)$ & $\%$ & 12.23 & 12.98 \\
\hline $\mathrm{CaCO}_{3}$ & $\%$ & 21.00 & 19.89 \\
\hline $\mathrm{SO}^{-2}$ (solubles) & ppm & 4358 & 2089 \\
\hline $\mathrm{Cl}^{-}$(solubles) & ppm & 212.85 & 156.40 \\
\hline $\mathrm{SiO}_{2}$ & $\%$ & 52.69 & 51.02 \\
\hline $\mathrm{Al}_{2} \mathrm{O}_{3}$ & $\%$ & 17.85 & 21.31 \\
\hline $\mathrm{Fe}_{2} \mathrm{O}_{3}$ & $\%$ & 7.15 & 6.92 \\
\hline $\mathrm{CaO}$ & $\%$ & 11.29 & 12.97 \\
\hline $\mathrm{MgO}$ & $\%$ & 4.24 & 2.72 \\
\hline $\mathrm{Na}_{2} \mathrm{O}$ & $\%$ & 0.394 & 0.757 \\
\hline $\mathrm{K}_{2} \mathrm{O}$ & $\%$ & 4.23 & 4.21 \\
\hline $\mathrm{TiO}_{2}$ & $\%$ & 0.868 & 0.827 \\
\hline $\mathrm{MnO}$ & $\%$ & 0.0502 & 0.0809 \\
\hline $\mathrm{P}_{2} \mathrm{O}_{5}$ & $\%$ & 0.195 & 0.275 \\
\hline Total $\mathrm{SO}_{3}$ & $\%$ & 0.570 & 0.120 \\
\hline
\end{tabular}

Table 2 Chemical analysis of sludge (W.W.T.P.: Waste Water Treatment Plant)

\begin{tabular}{lllll}
\hline Parameter & Units & W.W.T.P-A & W.W.T.P-B & W.W.T.P-C \\
\hline $\mathrm{O} . \mathrm{M} .500{ }^{\circ} \mathrm{C}$ & $\%$ & 58.13 & 54.13 & 56.20 \\
Deads $\left(1000{ }^{\circ} \mathrm{C}\right)$ & $\%$ & 65.98 & 64.64 & 66.12 \\
$\mathrm{CaCO}_{3}$ & $\%$ & 7.86 & 20.25 & 16.52 \\
$\mathrm{SO}^{-2}$ (solubles) & ppm & 8048.82 & 657.18 & 672.24 \\
$\mathrm{Cl}^{-}$(solubles) & ppm & 849.10 & 2664.43 & 1786.23 \\
$\mathrm{SiO}_{2}$ & $\%$ & 9.53 & 12.15 & 17.09 \\
$\mathrm{Al}_{2} \mathrm{O}_{3}$ & $\%$ & 5.37 & 6.19 & 8.80 \\
$\mathrm{Fe}_{2} \mathrm{O}_{3}$ & $\%$ & 16.70 & 15.24 & 4.26 \\
$\mathrm{CaO}$ & $\%$ & 26.24 & 32.18 & 42.46 \\
$\mathrm{MgO}$ & $\%$ & 2.55 & 1.66 & 1.73 \\
$\mathrm{Na}_{2} \mathrm{O}$ & $\%$ & 1.23 & 0.584 & 0.349 \\
$\mathrm{~K}_{2} \mathrm{O}$ & $\%$ & 1.65 & 0.997 & 1.46 \\
$\mathrm{TiO}_{2}$ & $\%$ & 0.883 & 1.15 & 1.25 \\
$\mathrm{MnO}$ & $\%$ & - & - & 0.0260 \\
$\mathrm{P}_{2} \mathrm{O}_{5}$ & $\%$ & 28.36 & 13.39 & 17.39 \\
$\mathrm{Total} \mathrm{SO}_{3}$ & $\%$ & 4.95 & 13.34 & 3.31 \\
Total & $\%$ & 97.46 & 96.88 & 98.13 \\
\hline
\end{tabular}


M.M. Jordán, M.B. Almendro-Candel, M. Romero, J.Ma. Rincón. Application of sewage sludge in the manufacturing of ceramic tile bodies

Applied Clay Science, 30 (2005) [3-4], 219-224; DOI: 10.1016/j.clay.2005.05.001

Table 3 Heavy metals content in RM1 and RM2 (oxides wt.\%)

\begin{tabular}{lll}
\hline Minor element & $\mathrm{RM} 1$ & $\mathrm{RM} 2$ \\
\hline $\mathrm{MnO}$ & 0.0503 & 0.0805 \\
$\mathrm{Rb}_{2} \mathrm{O}$ & 0.0158 & 0.0236 \\
$\mathrm{SrO}$ & 0.0821 & 0.0519 \\
$\mathrm{Y}_{2} \mathrm{O}_{3}$ & 0.0039 & 0.0044 \\
$\mathrm{ZrO}_{2}$ & 0.0282 & 0.0224 \\
$\mathrm{MoO}_{3}$ & 0.0022 & 0.0023 \\
$\mathrm{CdO}$ & $<$ d.1. & $<$ d.1. \\
$\mathrm{BaO}$ & 0.0620 & 0.0787 \\
$\mathrm{HgO}$ & $<$ d.1. & $<$ d.1. \\
$\mathrm{PbO}$ & $<$ d.1. & 0.0035 \\
\hline$<\mathrm{d} .1 .:$ less than the detection limit.
\end{tabular}

Table 4 Minor elements content in RM1 and RM2 (oxides wt.\%)

\begin{tabular}{lll}
\hline Minor element & RM1 & RM2 \\
\hline $\mathrm{MnO}$ & 0.0503 & 0.0805 \\
$\mathrm{Rb}_{2} \mathrm{O}$ & 0.0158 & 0.0236 \\
$\mathrm{SrO}$ & 0.0821 & 0.0519 \\
$\mathrm{Y}_{2} \mathrm{O}_{3}$ & 0.0039 & 0.0044 \\
$\mathrm{ZrO}_{2}$ & 0.0282 & 0.0224 \\
$\mathrm{MoO}_{3}$ & 0.0022 & 0.0023 \\
$\mathrm{CdO}$ & $<$ d.1. & $<$ d.1. \\
$\mathrm{BaO}$ & 0.0620 & 0.0787 \\
$\mathrm{HgO}$ & $<$ d.1. & $<$ d.1. \\
$\mathrm{PbO}$ & $<$ d.1. & 0.0035 \\
\hline$<\mathrm{d} .1 .:$ less than the detection limit.
\end{tabular}


M.M. Jordán, M.B. Almendro-Candel, M. Romero, J.Ma. Rincón. Application of sewage sludge in the manufacturing of ceramic tile bodies

Applied Clay Science, 30 (2005) [3-4], 219-224; DOI: 10.1016/j.clay.2005.05.001

Table 5 Heavy metals content in sludge from Waste Water Treatment Plants A, B and C, expressed in oxides \%

$\begin{array}{llll}\text { Heavy metals } & \text { W.W.T.P.-A } & \text { W.W.T.P.-B } & \text { W.W.T.P.-C } \\ \mathrm{V}_{2} \mathrm{O}_{5} & 0.0087 & 0.0176 & 0.0241 \\ \mathrm{Cr}_{2} \mathrm{O}_{3} & 0.0195 & 0.0309 & 0.0397 \\ \mathrm{Co}_{3} \mathrm{O}_{4} & 0.0138 & 0.0114 & <\mathrm{d} .1 . \\ \mathrm{NiO} & 0.0050 & 0.0221 & 0.0141 \\ \mathrm{CuO} & 0.068 & 0.269 & 0.167 \\ \mathrm{ZnO} & 0.311 & 0.438 & 0.338 \\ & <\text { d.1.: less than the detection limit. }\end{array}$

Table 6. Trace elements content in sludge from Waste Water Treatment Plants A, B and C, expressed in oxides \%

\begin{tabular}{|c|c|c|c|}
\hline Trace element & W.W.T.P.-A & W.W.T.P.-B & W.W.T.P.-C \\
\hline $\mathrm{MnO}$ & $<\mathrm{d} .1$. & $<\mathrm{d} .1$. & 0.0260 \\
\hline $\mathrm{Rb}_{2} \mathrm{O}$ & 0.0032 & 0.0050 & 0.0089 \\
\hline $\mathrm{SrO}$ & 0.565 & 0.563 & 0.314 \\
\hline $\mathrm{Y}_{2} \mathrm{O}_{3}$ & 0.0023 & 0.0048 & 0.0040 \\
\hline $\mathrm{ZrO}_{2}$ & 0.0588 & 0.0812 & 0.0658 \\
\hline $\mathrm{Nb}_{2} \mathrm{O}_{5}$ & 0.0042 & 0.0044 & 0.0042 \\
\hline $\mathrm{MoO}_{3}$ & 0.0117 & 0.0150 & 0.0116 \\
\hline $\mathrm{CdO}$ & $<$ d.l. & $<$ d.l. & $<$ d.l. \\
\hline $\mathrm{SnO}_{2}$ & 0.0177 & 0.0223 & 0.0246 \\
\hline $\mathrm{BaO}$ & 0.165 & 0.133 & 0.151 \\
\hline $\mathrm{HgO}$ & $<$ d.l. & $<$ d.l. & $<$ d.l. \\
\hline $\mathrm{PbO}$ & 0.0260 & 0.0473 & 0.0298 \\
\hline
\end{tabular}

bd.1.: less than the detection limit.

\section{Design of the green body}

After evaluating and discussing the analytical data, some experimental tests have been carried out with the RM1 ceramic clay and the sewage sludge B. Such tests consist of the preparation of mixtures with the following sludge percentage: 0 (control), 1, 1.5, 2, 3, 4, 5, 
M.M. Jordán, M.B. Almendro-Candel, M. Romero, J.Ma. Rincón. Application of sewage sludge in the manufacturing of ceramic tile bodies

Applied Clay Science, 30 (2005) [3-4], 219-224; DOI: 10.1016/j.clay.2005.05.001

7 and 10 (wt.\%). Ceramic bodies $(5 \times 5 \mathrm{~cm})$ have been prepared by uniaxial pressing and after dried in stove, they have been heated in a electric kiln following a standard heating cycle for high porosity ceramic bodies.

Determination of linear contraction and water absorption capacity

The linear contraction has been calculated in both dried (D.L.C.) and heated (H.L.C.) samples. The linear contraction is calculated as follows:

$\mathbf{L C}=\frac{L_{i}-\underline{E}_{f}}{L_{i}}+100$

where: $\mathrm{LC}=$ linear contraction $(\%), \mathrm{Li}=$ initial length of the ceramic body, $\mathrm{Lf}=$ final length of the ceramic body.

The water absorption capacity (\%) has been determined in heated ceramic samples. For it, a vessel is filled with water and heated until boiling. The ceramic bodies are introduced, separated from each other, after being weighed in water, so that they show as wide free surface as possible. The ceramic bodies are kept in the boiling water for two hours, and then the heat is interrupted. When the water reach the $35-40^{\circ} \mathrm{C}$ temperature range, the ceramic bodies can be taken out one by one, their surface is dried and they are weighed.

The value of the water absorption (WA) is obtained as follows:

$W A=\frac{w_{f}-w_{i}}{w_{i}}, 100$

$\underline{\text { Bending strength }}$

With the aim of determining the extent at which the sludge introduction in the ceramic paste affects the mechanical properties of the product, the bending strength of both dried and heated samples has been carried out in an INSTRON 1011 equipment using a 3-point loading method. Before carrying out the test the load speed was fixed at $0.02 \mathrm{~mm} / \mathrm{s}$ for dried bodies and $0.05 \mathrm{~mm} / \mathrm{s}$ for heated ceramic samples. The test were performed on ten 
M.M. Jordán, M.B. Almendro-Candel, M. Romero, J.Ma. Rincón. Application of sewage sludge in the manufacturing of ceramic tile bodies

Applied Clay Science, 30 (2005) [3-4], 219-224; DOI: 10.1016/j.clay.2005.05.001

specimens of each sample and the average values of bending strength were calculated by the equation:

$\sigma_{f}=\frac{3 P L}{2 t h^{2}}$

where: $\mathrm{F}=$ breaking load $(\mathrm{kg}), \mathrm{L}=$ distance between supports $(\mathrm{L}=29.67 \mathrm{~mm}), \mathrm{b}=$ sample width $(\mathrm{mm}), \mathrm{h}=$ sample thickness $(\mathrm{mm})$.

\section{Results and discussion}

With regard to the analysis of soluble salts $\left(\mathrm{Cl}^{-}\right.$and $\left.\mathrm{SO}_{4}^{-2}\right)$, it is obvious that the application of sludge would slightly increase the contents of these salts in the paste. However, due to the low percentage of sludge to be introduced in the paste, the total contents in soluble salts will be similar to those currently applied. From all these metals, cadmium, chrome, cupper, mercury, nickel, lead and zinc appear in the Spanish regulation, and their concentration in sludge is the factor, which determines their possible agricultural use. Cadmium and mercury are not detectable neither in sludge nor in the ceramic clays. In the sludge A, chromium appears in a concentration similar to the one appearing in the ceramic clays, whilst in the sludge $\mathrm{B}$ and $\mathrm{C}$ its concentration is slightly higher. Cupper is not detected in RM1 and is very low in RM2. In the case of the wastes, sludge A presents low values of this element, which increases in the case of sludge $B$ and even more in the $C$ one. Nickel appears in low concentrations in the sludge A in the ceramic clays, increasing in the sludge B and sludge C. As to lead, it is not detectable in RM1, being its concentration very low in RM2. Sludge A and $\mathrm{C}$ show lower contents of $\mathrm{Pb}$ than sludge $\mathrm{B}$. In the case of zinc, RM1 shows a very low value of this element, although it is slightly higher in RM2 while sludge show higher and more similar values from each other. Therefore, it would be convenient the use of the sludge for the manufacturing of traditional ceramics better than for an agricultural application (Manrique Fournier et al., 1990).

Fig. 1 shows the results of linear contraction tests in both dried and heated samples. It can be seen that there is no clear tendency in the results, which confirms that there is no 
M.M. Jordán, M.B. Almendro-Candel, M. Romero, J.Ma. Rincón. Application of sewage sludge in the manufacturing of ceramic tile bodies

relation between this technological property and the percentage of applied sludge. Fig. 2 shows the results of water absorption test. In this case, there is a clear tendency to increase as the quantity of sludge in the body increases. This fact was expected since the organic matter contained in the sludge is eliminated during the thermal process and it leads to an increase of the open porosity of the ceramic bodies.

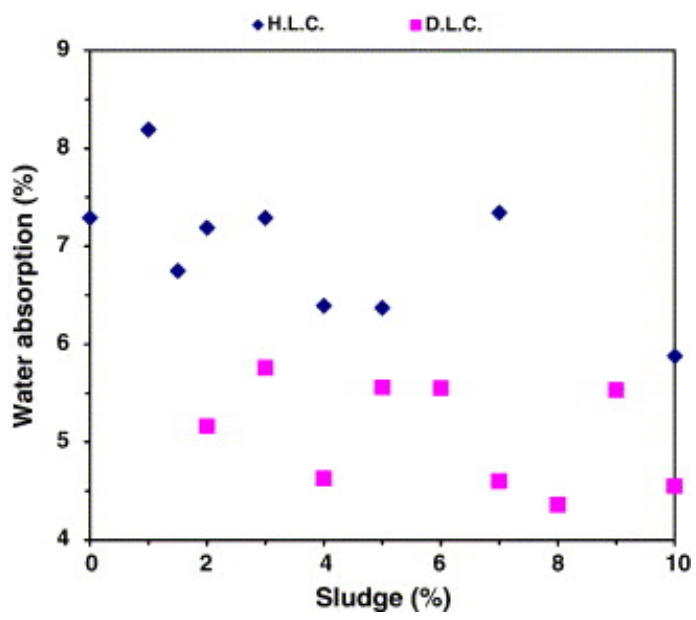

Fig. 1. Drying linear contraction (DLC) and heating linear contraction (HLC) expressed in $\%$ of ceramic bodies prepared with RM2 clay and sludge from Waste Water Treatment Plant B.

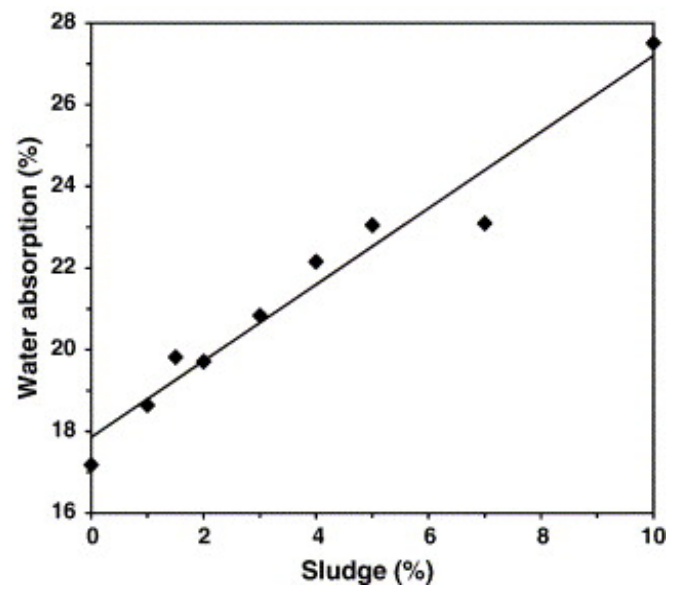

Fig. 2. Water absorption (\%) of ceramic bodies prepared with clay RM1 and sludge from Waste Water Treatment Plant B. 
M.M. Jordán, M.B. Almendro-Candel, M. Romero, J.Ma. Rincón. Application of sewage sludge in the manufacturing of ceramic tile bodies

Applied Clay Science, 30 (2005) [3-4], 219-224; DOI: 10.1016/j.clay.2005.05.001

The results of the bending strength are shown in Table 7. There is a slight decrease of this property when the addition of sludge increases.

Table 7. Flexural resistance of the original green body and the sintered ceramic after thermal cycling

\begin{tabular}{cll}
\hline \% Sludge & Green & Sintered \\
\hline 0 & 2.01 & 14.69 \\
1 & 1.70 & 11.56 \\
1.5 & 1.67 & 11.26 \\
2 & 1.43 & 11.03 \\
3 & 1.37 & 9.55 \\
4 & 1.67 & 8.60 \\
5 & 1.40 & 8.41 \\
7 & 1.42 & 8.66 \\
10 & 1.38 & 4.59 \\
\hline
\end{tabular}

\section{Conclusion}

The main advantages of the use of sewage sludge in the manufacturing of traditional ceramics are: recycling of a waste whose production increases every day with the installation of new Waste Water Treatment Plants, immobilization of heavy metals and reduction of raw materials costs. With regard to the technological properties of the final ceramics products manufactured, there seems not to be any clear relation between the values of linear contraction and the percentage of sludge. However, the increase of water absorption with the increase of the sludge percentage is clear, giving rise to a linear relation. On the other hand, the addition of sludge gives rise to a decrease of the bending strength, in such a way that the selection of the adequate percentage of sludge to be added to the body will be controlled by standards applied to specific construction materials. 
M.M. Jordán, M.B. Almendro-Candel, M. Romero, J.Ma. Rincón. Application of sewage sludge in the manufacturing of ceramic tile bodies

Applied Clay Science, 30 (2005) [3-4], 219-224; DOI: 10.1016/j.clay.2005.05.001

\section{References}

1. M.B. Almendro, J.Ma. Rincón, M.M. Jordán, M.S. Hernández. Eflorescencias en ladrillos. Materiales Inorgánicos en la Construcción para el Siglo XXI (Cerámicos, Vidrios, Piedra Natural y sus Composites), cap. 22, Universidad Miguel Hernández, Elche (Alicante) (2001), pp. 199-208

2. M.B. Almendro, M.M. Jordán, J. Navarro-Pedreño. Dinámica mineral de sulfatos en arcillas cocidas a $950{ }^{\circ} \mathrm{C}$. Datos preliminares. T. Sanfeliu, M.M. Jordán (Eds.), La investigación de arcillas en geología, agricultura, medio ambiente y ciencia de materiales, Universidad Miguel Hernández (2002), pp. 217-220

3. M. Bigeriego. Aplicación agronómica de lodos residuales. Curso sobre tratamiento de Residuos Urbanos CSIC-UAM (1993)

4. C.E. Clapp, S.A. Stara, D.E. Clay, W.E. Larson. Sewage sludge organics matter and soil properties. The Role of Organic Matter in Modern Agriculture, Martinus Nijhoff Publishers, Dordrecht (The Netherland) (1986)

5. R.D. Davis. Utilisation of sewage sludge in agriculture. Agric. Prog., 64 (1989), pp. $72-80$

6. M. Dondi, B. Fabbri, G. Guarini, M. Marsigli, C. Mingazzini. Soluble salts and efflorescence in structural clay products: a scheme to predict the risk of efflorescence. Bol. Soc. Esp. Cerám. Vidrio, 36 (6) (1997), pp. 619-629

7. M. Fernández. Manual sobre fabricación de baldosas, tejas y ladrillos. S.A. Beralmar (Ed.) (2000) Terrasa

8. F. González-García, V. Romero-Acosta, G. García Ramos, M. González Rodríguez. Firing transformations of mixtures of clays containing illite, kaolinite and calcium carbonate used by ornamental tile industries. Appl. Clay Sci., 5 (1990), pp. 361-375

9. M.M. Jordán, T. Sanfeliu, C. de la Fuente, E. Ballbé. Ceramic interest Weald clays from Castellon. Third Euro-Ceramics, vol. 2Faenza Editrice Iberica (1993), pp. 947952

10. M.M. Jordán, A. Boix, C. De la Fuente, E. Ballbé, I. Queralt, T. Sanfeliu. Mineralogía y propiedades cerámicas de arcillas cretácicas wealdienses de Castellón. Boletín de la Sociedad Española de Mineralogía, 17 (1994), pp. 135-143

11. M.M. Jordán, A. Boix, T. Sanfeliu, C. de la Fuente. The mineralogy of Cretaceous clays in Castellon and their application in the ceramic industry. Int. Ceram. J., 10 (1995), pp. 25-29

12. M.M. Jordán, A. Boix, T. Sanfeliu, C. de la Fuente. Firing transformations of cretaceous clays used in the manufacturing of ceramic tiles. Appl. Clay Sci., 14 (1999), pp. 225-234

13. M.M. Jordán, M.B. Almendro, E. García-Sánchez, J.Ma. Rincón. Patologías cerámicas asociadas a arcillas del Keuper de la provincia de Alicante. T. Sanfeliu, 
M.M. Jordán, M.B. Almendro-Candel, M. Romero, J.Ma. Rincón. Application of sewage sludge in the manufacturing of ceramic tile bodies

Applied Clay Science, 30 (2005) [3-4], 219-224; DOI: 10.1016/j.clay.2005.05.001

M.M. Jordán (Eds.), La investigación de arcillas en geología, agricultura, medio ambiente y ciencia de materiales, Universidad Miguel Hernández (2002), pp. 243-246

14. A. Manrique Fournier, I. Walter, I. Arroyo González. Metales pesados como factor limitante a la utilización agrícola de lodos residuales urbanos. 1er Congreso Internacional de Química de la ANQUE, vol. II (1990), pp. 479-485 (Tenerife)

15. R. Miralles, E. García-Sánchez, M.M. Jordán. Estudio ambiental de antiguas explotaciones de margas-yesos del Trias-Keuper de la provincia de Alicante. T. Sanfeliu, M.M. Jordán (Eds.), La investigación de arcillas en geología, agricultura, medio ambiente y ciencia de materiales, Universidad Miguel Hernández (2002), pp. $183-193$

16. J. Navarro Pedreño, I. Gómez, R. Moral, G. Palacios, J. Mataix. Heavy metals and plant nutrition and development. Recent Res. Dev. Phytochemistry, 1 (1997), pp. 173-179

17. T.J. Peters, J.P. Jenny. Mineralogical study of the firing characteristics of brick clays. Beitr. Geol. Schweitz Geotech., 50 (1973), p. 59 (Switzerland)

18. G.G. Pollifrone, A. Ravaglioly. Le argile: compendio genetico, mineralogico e chimico físico. Ceram. Inf., 7 (20) (1973), pp. 565-581

19. Real, C. 1977. Análisis por difracción de rayos $X$ de fases de alta temperatura resultantes de materias primas de interés industrial. Tesis. Fac. de Ciencias. Universidad de Sevilla.

20. L.E. Sommers. Chemical composition of sewage sludges and the analysis of their potential use as fertilizers. J. Environ. Qual., 6 (1977), pp. 225-232 